\title{
Applying Blended Learning Method in Teaching English at the University of Da Nang, Viet Nam
}

\author{
Pham Thi Thu Huong \\ ESP Department, University of Foreign Language Studies, the University of Da Nang, Viet Nam
}

How to cite this paper: Huong, P. T. T. (2018). Applying Blended Learning Method in Teaching English at the University of Da Nang, Viet Nam. The Educational Review, USA, 3(1), 16-21.

http://dx.doi.org/10.26855/er.2019.01.002

Corresponding author: Pham Thi Thu Huong, ESP Department, University of Foreign Language Studies, the University of Da Nang, Viet Nam.

\begin{abstract}
Blended learning addresses the way e-learning is combined with traditional teaching method and independent study approach to create a new, hybrid teaching methodology which has been increasingly applied in teaching foreign languages today. However, it requires a fundamental change in the way students approach the learning methods which, in turn, could bring about expecting or unexpecting results. Therefore, this paper aims to discuss advantages and challenges that students, especially non-English major students of the University of Da Nang, often face when they take some blending English courses. The researcher has set up and studied three groups of students with different majors, namely economics, technology, and business English - from different universities belonging to the University of Da Nang, who are taking some blending English courses such as DynEd, Life or other ones designed on Moodle platform by teachers of English. Because of differences in the major,the objectives of studying English, and incoming English proficiency of these three groups of students, their attitudes toward and English learning results could be not simillar, or even extremelly different. However, the factors which have big influence on these students' learning results are their inappropriate application of blended learning approach and their unadequate practice experience on using IT tools as taking blended English courses. Besides, the paper attemps to suggest some solutions to challenges that students often deal with as taking English courses in blended environment under the real pedagogical conditions in Vietnam.
\end{abstract}

\section{Keywords}

Blended Learning, Benefits, Challenges, Online, Face-to-Face

\section{Introduction}

During the last few decades, the rapid development of Information Technology (IT) has strong effects on various aspects of our life, especially on education. IT can be considered as an unseperated vital part of the foreign language education in the modern life leading to considerable changes in foreign language teaching and learning approaches in which blended learning has become a dominant one and implemented by language teachers worldwide during the progress of foreign language teaching and learning innovation.

Since 2012, the University of Foreign Language Studies, Da Nang University (in participating with several other Universities of Foreign Languages in Viet Nam) has carried out the national foreign language project 2020 in higher education insititution s via implementing blended EFL courses for both English-major and Non-English-major students of Da Nang University such as DynEd, Life, Skillful or other ones designed on the Internet platform Moodle by teachers of English. With the hypothesis is 
that the differences in students'major, students' input and required outcome of English competency, and in their knowledge and practice experience on IT could bring them disimilar learning results, this study is carried out to confirm the hypothesis and find out benefits and challenges that students often deal with as taking English foreign language (EFL) courses in blended environment.

\subsection{Definitions of Blended Learning}

Although the term blended learning is widely used in education, there is no universally accepted definition of blended learning (Graham, 2012). While some definitions refer to a combination of different delivery media, of instructional methods or of face-to-face and online instruction (Bonk \& Graham, 2012; Graham, 2013), others define it as the combination of online and face-to-face learning and teaching depending on the proportion of course content delivered online (Picciano, 2013). This study, however, tend to base on the definition of Garrison and Vaugan (2008) which stated that blended learning is considered as the organic integration of thoughtfully selected and complementary face-to-face and online approaches, because this concept more focuses on the pedagogical aspect of the combination and depends largely on its implementation context. (Tue, 2015).

\subsection{Types of Blended Learning}

There are many ways to categorise blended learning. For example, blended learning can be classified into Activity level, Course level, Program level, and Institutional level according to the levels of implementation; classified as Skill-driven, Attitude-driven, and Competency-driven models in concern with the learning objectives; or as Enabling blends, Enhancing blends, and Transforming blends in terms of learning scope of blended learning (Graham, 2012; Valiathan, 2002). Among these types of blended learning, Enhancing blends and Transforming blends are the two most significant to this study because they show incremental change to existing padagogy such as offering supplementary online materials for face-to-face courses, or changing from a model where EFL learners are merely receivers of information to a model where learners actively construct English knowledge and skills through rich interactions with others in both face-to-face and online environments (Tue, 2015) which has brought valuable contribution into the process of foreign language teaching and learning innovation.

\subsection{Fundamental Theories for Implementing Blended Learning in EFL Education}

According to Lamy \& Halmpel (2007), the design of transformative EFL blended learning has its theoretical foundation in cognitive constructivism and socio-cultural constructivism theories. This paper, however, takes the later into account much more than the former. The reason for this is that

cognitive constructivism is most concerned with the mechanism of intellectual development and acquisition of knowledge which occurs internally; meanwhile, socio-cultural constructivism highlights the role that social processes and interactions play in individual's intellectual development, emphasising that those social processes and interactions are culturally situated (Tue, 2015).

Socio-cultural constructivism itself includes the notion of mediation and social learning. From social-cultural perspectives, the EFL learning process of some student is mediated by others such as teachers, peer students, by cultural artefacts like language, cultural history, social context, electronic forms of information access, and so on and by the self through private speech or private imitation (Lantolf, 2000). Besides, the concept of social learning provides theoretical support for the use of ICT in EFL education and emphasises the importance of a supportive discourse for EFL learning since as a social activity, learning involves individual-collective processes of identification and identity construction (Pavlenko \& Norton, 2007).

Going along with these two theories, five pedagogical principles of Wilson (2008) are applied in this studies because they define what teachers do to create effective learning in blended learning environments. These principle are: (1) promoting learning engagement, (2) providing timely feedback, (3) providing for learner control of their own learning, (4) providing opportunities 
for dialogue and communication, and (5) motivating students in a variety of ways.

\section{Main Study}

\subsection{Reasearch Design and Participants}

Both quantitative and qualitative methods are used for accomplishing the goal of the study. The quantitative method was applied (with the investigating tool of questionnaire) to colect the information of benefits and challenges frequently dealed by students as taking blended English courses; The qualitative one which was the interview of some students with their typical learning results enables the researcher to explore the students' perspective of blended learning and experience on using IT as taking EFL courses in blended environment.

The study involved three groups of student participants as listed in Table 1 below.

Table 1. Three groups of student participants.

\begin{tabular}{llllll}
\hline Group & \multicolumn{1}{c}{ Participants } & $\begin{array}{c}\text { Students' } \\
\text { major } \\
\text { competency }\end{array}$ & $\begin{array}{c}\text { Required out- } \\
\text { come of English } \\
\text { competency }\end{array}$ & English course \\
\hline 1 & $\begin{array}{l}45 \text { first-year students ages 18-20 }(7 \\
\text { males and } 38 \text { females) from the }\end{array}$ & Business & English \\
University of Foreign Language \\
Studies.
\end{tabular}

\section{Results and Analysis}

The data collection and analysis for this study were conducted simutane ously in the second semester of the academic year 2016-2017.

To colect the information of benefits and challenges dealed by students as taking blended English courses, a questionnaire including six main questions relating to six issues as follows: (1) the advantages and disadvantages of the online learning resources; (2) the access ability and quality of online English courses; (3) the relationship between the content of online lessons and face-to-face learning activities in classroom; (4) the effectiveness of blended learning method in improving students' English competence; (5) their favourite components of blended courses; and (6) the influence of their IT knowledge and experience on using IT tools as implementing blended English courses.

From the above results presented in figure 1, we can find that $78 \%$ student participants recognized big advantages of the online resources without any complains. The advantages they could get as taking these blended English courses include interesting style-plentiful learning sources, costless online learning materials such as audio or download-free printsheets of guidebook, wordlist, etc., attractive outlook and utilities with user-friendly interfaces of the webpage. The rest ones (22\%) mentioned to some disadvantages 
of sofware DynEd such as component Voice Regcognition, some misunderstandable principles that they have to follow to get the Mastery Test; or participants of group 3 complainted about the time limitation of exploring free learning resource linked with online course Solutions designed on platform Moodle. However, these disadvantages partly come from students' lack of knowledge and skills for self-study.

Their feedback on issue 2 led to similar results as that of the first issue. Most of the student partici pants gave good evaluation of the quality of the three online English courses, especially course Life on English learning webpage National Geographic. They gave high vote to the flexible access ability of software DynEd which automatically flips the switch and hence it can save and keep all detailed records of their learning process in case the Internet turns off suddenly. However, 7 students (15.4\%) from group 2 expressed their negative comments on the instructions for registration procedure and the first access to course Life. According to them, it is quite complex and confusing for them to follow and hence accomplish the registration steps at the first access session.

Basing on the aggrement of 97 students participants to give positive feedback to issue 3 and 4 , the researcher find that there is a close relationship between the content of online lessons and classroom learning activities concerning course Life and course Soluti ons. Most activities included in these courses can be considered as the extra lessons or further exercises which not only provide learners with many more opportunities of practising English skills but also enrich their knowledge of culture and society via plentiful social-culural themes of the lessons. Due to this, their English competency has been considerably improved. 93 student participants recognised their pronounciation and their communicating skill (listening and speaking) had became better, their vocabulary and knowlege of English grammar had been enriched and as the result their writing skill had been partly improved.

In regarding to the students' favourite components of blended EFL courses, $82 \%$ of 118 student participants voted for online parts which are mainly video clips, audio, 40 among 45 students of group 1 liked component Voice Recognition (in software DynEd), 28 among 31students of group 3 were fond of games, quize integrated in course Solutions designed on platform Moodle beccause the se parts brought them really interesting and useful knowlege, they also made learners less stressed, more relaxing in compared with the traditional English exercises or homework. About $67 \%$ of the total participants likes the online tutor (software DynEd) or gradebook (course Life) because this part not only gives them immediate assessment on their tasks but also lets them know about a lot of details of their self-studying sessions, their goodpoints and badpoints, and suggestions to improve their learning results. Unlike the $67 \%$ participants, the rest ones were not interested in this part. The reasons for their dislike here is that they misunderstood the online tutor's feedback and were abit afraid of their badpoints to be shown to other classmate or peers. The part occupied the smallest numb er of likes from the participants $(41 \%)$ is the face-to-face activities in classroom. These students voted for this part because it put them into real communication sessions with the real communicators and the most real-like communicating situations that required them to try their best to immediately react and get as many sound results as possible.

The participants' feedback to issue 6 shows that more than two thirds of them ( 83 students) had no or little knowledge and practice experience of IT even though the major of student participants from group 3 is Computer Science. This fact turned into a big obstacle for students to effectively exploit all advantages and easily overcome some disadvantages (for example difficulty in using IT tools to record their voice, to submit their assignment online, or to quickly accomplish registration procedure at the first online learning sessions, etc.) of these blended EFL courses as well. Therefore, the reseacher can conclude that the students need much more training of IT and opportunities of practising using IT tools commonly used in language learning sofware or webpages before taking blended English courses.

To collect the data of the students' experience of practising IT in their learning process, the researcher interviewed six st udents (named student \# 1 to student \# 6) from these three universities whose learning results of these blended English courses were the best or the worst among each group.

With the question "Do you think you have enough experience on practising IT tools before take these online English course?", all of them gave "No" answer. However, three students with the best learning results and both two students with their major of Computer 
Science paid their small attention to this via the sixth student's answer "I know I am not good at IT, but I can do all tasks in the course that required using some IT tools well. Maybe, it is because these tools are common and very familar to me", or via the answer of the student from the University of Foreign Language Studies: "I had not taken any IT courses before taking this English course, but I did not worry about that much because I could use them effectively by following the instructions given in the course". However, all of six students said "Yes" when being asked "Do you want to get some more trainning to improve your IT skills?". Especially, the student who was from University of Economics and Adinistration and had the worst learning result implicated his strong expectation for the further IT training via his answer: "My English is very bad and so is my IT skill. I think that may cause such my learning result. I want to get more opportunities to practise to be able to use IT tools better."

In concerned with the students' perspective on blended learning, five of them expressed their positive attitude excepting for one student whose living condition is not good. All the students agreed with the statement of one student with the major of Computer Science: "Although we have not been familar to self-study style, blended learning makes us more motivated and hence study more actively than the traditional learning style. I think it the most suitable English learning approach in the present digital a ge."

\section{Conclusion}

There are both advantages and challenges as applying blended learning approach in teaching English. Under the real pedagogical conditions in Vietnam, the advatages or the benefits that students often get as taking blended English courses include: interesting and plentiful learning sources, costless online learning materials, more opportunities to practise communicating skills and improve their English competency, and better motivation and engagement in their self-study and active participation in face-to-face learning activities. The main challenges for students are students' lack of knowledge and skills for self-study and unadequate practice experience on using IT tools for taking online English course. In spite of the difference in their English learning results, however, most of the students have positive perspective on blended learning and expectation of getting some more IT training to overcome the obstacle of IT skill and hence improve their English competency. Therefore, this paper also suggests students mastering Wison's theory of blended learning and principles of self-study and appropriately applying them in implementing EFL courses in blended learning environment.

\section{References}

Bonk, C. J., \& Graham, C. R. (2012). The Handbook of Blended Learning: Global Perspectives, Local Designs. Hoboken: Pfeiffer.

Garrison, D. R., \& Vaughan, N. D. (2008). Blended Learning in Higher Education: Framework, Principles, and Guidelines. San Francisco: Jossey-Bass.

Graham, C. R. (2012). Blended Learning Systems: Definition, Current Trends and Future Directions. In C. J. Bonk \& C. R. Graham (Eds.), The Handbook of Blended Learning: Global Perspectives, Local Designs (pp. 63-95). Hoboken: Pfeiffer.

Graham, C. R., Woodfield, W., \& Harrison, J. B. (2013). A Framework for Institutional Adoption and Implementation of Blended Learning in Higher Education. The Internet and Higher Education, 18(2013), 4-14. doi: http://dx.doi.org/10.1016/j.iheduc.2012.09.003

Lamy, M. N., \& Hampel, R. (2007). Online Communication in Language Learning and Teaching. Basingstoke: Palgrave Macmillan Ltd.

Lantolf, J. P. (2000). Second Language Learning as a Mediated Process. Language Teaching, 33(2), 79-96.

Pavlenko, A., \& Norton, B. (2007). Imagined Communities, Identity, and English Language Learning. In J. Cummins \& C. Davison (Eds.), International Handbook of English Language Teaching. New York: Springer.

Picciano, A. G., Dziuban, C. D., \& Graham, C. R. (2013). Blended Learning: Research Perspectives, Volume 2. New York \& London: Routledge Ltd.

Tue, H.N. (2015). EFL Teachers' Perceptions and Experiences of Blended Learning in a Vietnamese University. https://eprints.qut.edu.au/83945/1. 